But - and this again is what I take to be current Government health policy along the lines of Health Authorities buying in services - there would be an ingenious differential payment for different categories. Without going into tedious cost benefit analysis, in broad principle the more preferred patients would cost the psychiatrist more-and the profit from this would be used to compensate the psychiatrist taking the less preferred patient, longstay or whatever, a sort of merit award.

The operation, I must stress, would of course be entirely non profit making as far as the Central Agency would be concerned - setting aside a small sum for administrative expenses and the unit managers of the Agency.

The idea, I admit has its deficiences. It is unfortunate that it does not cater for the needs of those psychiatrists who are drawn towards committee work and consensus management: but they could always become elected or co-opted members of the Agency. Think about it.

Old Rectory House

Chapter House Street, York

ARTHUR Bowen

\section{Mental Health Review Tribunals}

DeAr Sirs

I have become increasingly embarrassed and saddened, as a member of the South Western Mental Health Review Tribunal, at the somewhat cavalier attitude of some of our psychiatric colleagues towards attendance at, in particular, Section 2 hearings which, of necessity, have to be arranged at short notice. This presents a major logistical exercise for a tiny, but very conscientious, Tribunal office staff, in finding legal, medical and lay members all available at the same time and the same day, often after a journey of many miles. Having done this, I feel it is neither courteous nor helpful for the RMO to refuse to attend at the appointed time because he has a previous out-patient appointment or to complain if there is any unforeseen delay in proceeding on the day of the hearing.

I believe that the majority of Tribunal members, legal, lay and medical, may well share the widespread doubts of many colleagues about the justification for Section 2 appeals, but, the fact is that the 1983 Act still requires them, and that however inconvenient they are a burden we all have to share.

Although Tribunals are usually conducted in a relatively informal manner, they remain a statutory, legal forum, which deserves, I suggest, the respect of at least a tie, if not a jacket, from medical (and other staff?) appearing before it.

Flat 2, 38 Apsley Road

W. Alan Heaton-Ward Clifton, Bristol BS8 2SS

\section{Royal Prerogative?}

DeAr Sirs

I am a consultant psychiatrist working in mental handicap. As part of the assessment of the degree of handicap of the patients that I am asked to see, I administer a short test. One of the questions involved concerns the sex and name of the monarch.

Of the last five patients to whom I have given this questionnaire, four accurately stated that there was a queen on the throne. However, three of these were confused about the identity of the person, confidently stating that her name was Mrs Thatcher. Sic transit gloria reginae.

Prudhoe Hospital

STEPHEN P. TYRER 